\title{
In vitro and in vivo a-amylase and a- glucosidase inhibiting activities of the protein extracts from two varieties of bitter gourd (Momordica charantia L.)
}

Sundar Poovitha and Madasamy Parani*

From Indian Genetics Congress 2015

Kattankulathur, India. 4 - 6 March 2015

\begin{abstract}
Background: a-amylase and a-glucosidase digest the carbohydrates and increase the postprandial glucose level in diabetic patients. Inhibiting the activity of these two enzymes can control postprandial hyperglycemia, and reduce the risk of developing diabetes. Bitter gourd or balsam pear is one of the important medicinal plants used for controlling postprandial hyperglycemia in diabetes patients. However, there is limited information available on the presence of a-amylase and a-glucosidase inhibiting compounds. In the current study, the protein extracts from the fruits of M. charantia var. charantia (MCC) and M. charantia var. muricata (MCM) were tested for a-amylase and a-glucosidase inhibiting activities in vitro, and glucose lowering activity after oral administration in vivo.

Results: The protein extract from both MCC and MCM inhibited the activity of a-amylase and a-glucosidase through competitive inhibition, which was on par with Acarbose as indicated by in vitro percentage of inhibition ( 66 to $69 \%$ ) and IC50 (0.26 to $0.29 \mathrm{mg} / \mathrm{ml})$. Both the protein extracts significantly reduced peak blood glucose and area under the curve in Streptozotocin-induced diabetic rats, which were orally challenged with starch and sucrose.

Conclusions: Protein extracts from the fruits of the two varieties of bitter gourd inhibited a-amylase and a-glucosidase in vitro and lowered the blood glucose level in vivo on par with Acarbose when orally administrated to Streptozotocin-induced diabetic rats. Further studies on mechanism of action and methods of safe and biologically active delivery will help to develop an anti-diabetic oral protein drug from these plants.
\end{abstract}

Keywords: a-amylase, a-glucosidase, Momordica charantia, Competitive inhibition, Peak blood glucose

\section{Background}

In diabetes mellitus, homeostasis of carbohydrate and lipid metabolism is altered due to defects in insulin production or action. It is a major non-communicable metabolic disease involving huge healthcare cost and high mortality rate. The number of adults with diabetes was estimated to be 387 million, and diabetes alone caused 4.9 million deaths in the year 2014 [1]. Postprandial hyperglycemia (PPHG) is a condition in which blood glucose level

\footnotetext{
* Correspondence: parani.m@ktr.srmuniv.ac.in

Genomics Laboratory, Department of Genetic Engineering, SRM University, Kattankulathur, Chennai 603203, India
}

remains high after consuming meal, and it is an important factor to be considered in the management of diabetes mellitus and diabetes related secondary complications such as diabetic retinopathy, diabetic neuropathy, cardiovascular diseases, etc. [2]. Glycosidic linkages of $\alpha$-D-(1,4) in carbohydrates are cleaved by $\alpha$-amylase to produce oligosaccharides, which are further cleaved to monosaccharide glucose by $\alpha$-glucosidase [3]. Therefore, inhibitors of these enzymes can delay the increase in blood glucose level in people who consume carbohydrate-rich food, and keep the PPHG under control [4]. 
Acarbose, Miglitol, and Voglibose are the enzyme inhibitors that are currently used for controlling PPHG. Acarbose inhibits both $\alpha$-amylase and $\alpha$-glucosidase, but Miglitol and Voglibose inhibit only $\alpha$-glucosidase. Though effective in controlling PPHG, these inhibitors are not desirable for long-term treatment due to their gastrointestinal side effects [5, 6]. Given the fact that about $80 \%$ of the diabetic people are living in low and middle income countries [7], these drugs are expensive also. Therefore, several groups have made their efforts to find $\alpha$-amylase and $\alpha$ glucosidase inhibitors from plants, bacteria, marine algae, and fungi [8-11]. Majority of them have studied the crude extracts (organic or aqueous), and some have studied pure compounds also [12, 13]. Most of the plant extracts and pure compounds were effective against either $\alpha$-amylase or $\alpha$-glucosidase, with a few exceptions being effective against both enzymes $[14,15]$.

Presence of antidiabetic activity in Momordica charantia (bitter gourd or balsam pear) was identified as early as in 1963 [16]. Extracts from fruit pulp, seeds, leaves and whole plants of $M$. charantia were shown to have hypoglycemic effects [17]. Methanol extracts from the fruits and seeds of $M$. charantia exhibited $\alpha$-glucosidase inhibiting activity [18-20]. Fasting and postprandial blood glucose levels in diabetes patients were reduced after the oral intake of the aqueous extract from $M$. charantia fruit pulp [21]. Clinical trials using an insulinlike protein from $M$. charantia fruit pulp showed hypoglycemic activity in diabetes patients [22]. In vivo hypoglycemic, insulin-mimetic, and insulin secretagogue activities were also reported for the protein extracts from $M$. charantia [23, 24]. However, there was no direct evidence to show that the protein extracts from $M$. charantia have $\alpha$-amylase and $\alpha$-glucosidase inhibiting activities. Therefore, the current study was undertaken to evaluate the protein extracts from the fruits of two varieties of $M$. charantia for $\alpha$-amylase and $\alpha$ glucosidase inhibiting activities in vitro and glucose lowering activity in vivo using Acarbose as reference.

\section{Methods}

\section{Materials}

The fruits of $M$. charantia var. charantia (MCC) and $M$. charantia var. muricata (MCM) were bought from the local market in Chengalpet, Tamil Nadu, India. They were taxonomically identified by a botanist and verified by DNA barcoding. Porcine $\alpha$-amylase and yeast $\alpha$-glucosidase were bought from Sigma Aldrich, and Acarbose from Bayer AG (Germany).

\section{Protein extraction}

Proteins were extracted from the fruit pulp of the two varieties of $M$. charantia as described before [24] with minor modifications. Fresh pulp was ground with ice- cold acid-ethanol, filtered through a muslin cloth, and centrifuged at $8000 \times \mathrm{g}$ for $10 \mathrm{~min}$. The $\mathrm{pH}$ of the supernatant was adjusted to 3.0 using ammonia solution. Four volumes of acetone was added, mixed gently, and incubated at $4{ }^{\circ} \mathrm{C}$ for $24 \mathrm{~h}$. The mixture was centrifuged at $6000 \times \mathrm{g}$ for $10 \mathrm{~min}$. The pellet was washed with $80 \%$ acetone, air dried, and dissolved in $10 \mathrm{mM}$ Tris $-\mathrm{HCl}$, $\mathrm{pH}$ 8.0.

\section{a-amylase inhibition assay}

Stock solutions of protein extracts and Acarbose were prepared in water. Inhibition of porcine $\alpha$-amylase activity was determined using dinitrosalicylic acid as described before [25]. Protein extract or Acarbose $(100 \mu \mathrm{l}$ of 2 to $20 \mathrm{mg} / \mathrm{ml}$ ) was added to $100 \mu \mathrm{l}$ of $\alpha$-amylase (1 $\mathrm{U} / \mathrm{ml})$ and $200 \mu \mathrm{l}$ of sodium phosphate buffer $(20 \mathrm{mM}$, $\mathrm{pH} 6.9$ ) to get 0.5 to $5.0 \mathrm{mg} / \mathrm{ml}$ final concentration. The samples were pre-incubated at $25{ }^{\circ} \mathrm{C}$ for $10 \mathrm{~min}$, and $200 \mu \mathrm{l}$ of $1 \%$ starch prepared in $20 \mathrm{mM}$ sodium phosphate buffer ( $\mathrm{pH}$ 6.9) was added. The reaction mixtures were incubated at $25{ }^{\circ} \mathrm{C}$ for $10 \mathrm{~min}$. The reactions were stopped by incubating the mixture in a boiling water bath for $5 \mathrm{~min}$ after adding $1 \mathrm{ml}$ of dinitrosalicylic acid. The reaction mixtures were cooled to room temperature, diluted to 1:5 ratio with water, and absorbance was measured in a spectrophotometer (Amersham Biosciences, USA) at $540 \mathrm{~nm}$. Percentage of inhibition of enzyme activity was calculated as

$$
\% \text { Inhibition }=\left[\left(\mathrm{A}_{540}{ }^{\mathrm{Control}}-\mathrm{A}_{540}{ }^{\text {Treatment }}\right) / \mathrm{A}_{540}{ }^{\mathrm{Control}}\right] \times 100
$$

wherein $\mathrm{A}_{540}^{\text {Control }}$ is absorbance at $540 \mathrm{~nm}$ in control sample without protein extract and $A_{540}^{\text {Treatment }}$ is absorbance at $540 \mathrm{~nm}$ in treatment with protein extract

\section{a-glucosidase inhibition assay}

Inhibition of $\alpha$-glucosidase activity was determined using yeast $\alpha$-glucosidase and $p$-nitrophenyl- $\alpha$-D-glucopyranoside (pNPG) as described before [26]. Protein extract or Acarbose $(100 \mu \mathrm{l}$ of 2 to $20 \mathrm{mg} / \mathrm{ml})$ was added to $50 \mu \mathrm{l}$ of $\alpha$-glucosidase $(1 \mathrm{U} / \mathrm{ml})$ prepared in $0.1 \mathrm{M}$ phosphate buffer ( $\mathrm{pH} 6.9)$, and $250 \mu \mathrm{l}$ of $0.1 \mathrm{M}$ phosphate buffer to get 0.5 to $5.0 \mathrm{mg} / \mathrm{ml}$ final concentration. The mixture was pre-incubated at $37{ }^{\circ} \mathrm{C}$ for $20 \mathrm{~min}$. After pre-incubation, $10 \mu \mathrm{l}$ of $10 \mathrm{mM}$ pNPG prepared in $0.1 \mathrm{M}$ phosphate buffer ( $\mathrm{pH}$ 6.9) was added, and incubated at $37{ }^{\circ} \mathrm{C}$ for $30 \mathrm{~min}$. The reactions were stopped by adding $650 \mu \mathrm{l}$ of $1 \mathrm{M}$ sodium carbonate, and the absorbance was measured in a spectrophotometer (Amersham Biosciences, USA) at $405 \mathrm{~nm}$. Percentage of inhibition of enzyme activity was calculated as 


$$
\% \text { Inhibition }=\left[\left(\mathrm{A}_{405}{ }^{\mathrm{Control}}-\mathrm{A}_{405}{ }^{\text {Treatment }}\right) / \mathrm{A}_{405}{ }^{\mathrm{Control}}\right] \times 100
$$

wherein $\mathrm{A}_{405}^{\text {Control }}$ is absorbance at $405 \mathrm{~nm}$ in control sample without protein extract and $\mathrm{A}_{405}^{\text {Treatment }}$ is absorbance at $405 \mathrm{~nm}$ in treatment with protein extract

\section{Analysis of proteolytic activity}

Proteolytic activity of the plant extracts was tested against $\alpha$-amylase $(2 \mathrm{U} / \mathrm{ml}), \alpha$-glucosidase $(0.05 \mathrm{U} / \mathrm{ml})$ and a mixture of six unrelated proteins ( $\beta$-lactalbumin, lysozyme, soybean trypsin inhibitor, ovalbumin, bovine serum albumin, and phosphorylase-b, $5 \mu \mathrm{g}$ ). These samples were treated with $20 \mu \mathrm{g}$ of the protein extracts from MCC and MCM for $10 \mathrm{~min}$ at $25{ }^{\circ} \mathrm{C}(\alpha$-amylase and mixture of six proteins) or $37{ }^{\circ} \mathrm{C}$ ( $\alpha$-glucosidase). Treatment with Proteinase $\mathrm{K}\left(55^{\circ} \mathrm{C}\right.$ for $\left.1 \mathrm{~h}\right)$, and heat denatured protein extracts were used as positive and negative controls, respectively. The reactions were stopped by heating the samples at $100{ }^{\circ} \mathrm{C}$ for $5 \mathrm{~min}$ after adding protein loading dye to a final concentration of $1 \mathrm{X}$. The samples were analyzed by $12 \%$ SDS-PAGE.

\section{Mode of inhibition assay}

Mode of inhibition of $\alpha$-amylase and $\alpha$-glucosidase by the protein extracts was determined as described before [27]. For $\alpha$-amylase, the enzyme solution $(1 \mathrm{U} / \mathrm{ml})$ was pre-incubated with protein extracts $(10 \mathrm{mg} / \mathrm{ml})$, Acarbose $(10 \mathrm{mg} / \mathrm{ml})$ or phosphate buffer $(\mathrm{pH} 6.9)$ at $25{ }^{\circ} \mathrm{C}$ for $10 \mathrm{~min}$. The reactions were started by adding 5 to $25 \mathrm{mg} / \mathrm{ml}$ starch, and continued at $25{ }^{\circ} \mathrm{C}$ for $10 \mathrm{~min}$. The reactions were stopped by adding $0.5 \mathrm{ml}$ of dinitrosalicylic acid followed by boiling for $5 \mathrm{~min}$. For $\alpha$ glucosidase, the enzyme solution $(1 \mathrm{U} / \mathrm{ml})$ was preincubated with protein extracts $(10 \mathrm{mg} / \mathrm{ml})$, Acarbose $(10 \mathrm{mg} / \mathrm{ml})$ or phosphate buffer $(\mathrm{pH} 6.9)$ at $25{ }^{\circ} \mathrm{C}$ for $10 \mathrm{~min}$. The reactions were started by adding 50 to $250 \mathrm{mg} / \mathrm{ml} \mathrm{pNPG}$, and continued at $25{ }^{\circ} \mathrm{C}$ for $10 \mathrm{~min}$. The reactions were stopped by adding $0.05 \mathrm{ml}$ of $1 \mathrm{M}$ sodium carbonate. Release of reducing sugars was quantified using maltose and paranitrophenol standard curve. Double reciprocal plot $(1 / v$ versus $1 /[\mathrm{S}])$ where $v$ is reaction velocity and $[\mathrm{S}]$ is substrate concentration was plotted. Mode of inhibition was determined by analysing Lineweaver-Burk plot using Michaelis-Menten kinetics.

\section{Induction of diabetes in Wistar rats}

Forty male Wistar rats (3-months old) were purchased from King's Institute, Chennai, and kept under 12:12 h light and dark cycle at $25 \pm 2{ }^{\circ} \mathrm{C}$. The diabetic animals were fed with high fat diet and water ad libitum throughout the treatment period of 30 days. The experimental protocols were conducted in accordance with internationally accepted principles for laboratory animal use and were approved by the Institutional Animal Ethical Committee
(087/835/IAEC-2014). Diabetes was induced in $18 \mathrm{~h}$ fasted animals by intraperitoneal injection of $110 \mathrm{mg} / \mathrm{kg}$ nicotinamide followed by $45 \mathrm{mg} / \mathrm{kg}$ Streptozotocin (freshly dissolved in $0.1 \mathrm{M}$ citrate buffer, $\mathrm{pH}$ 4.5). Tail bleeds were performed 7 days after injecting Streptozotocin, and animals with blood glucose concentration above $250 \mathrm{mg} / \mathrm{dL}$ were considered diabetic.

\section{Oral starch and sucrose tolerance tests}

Oral starch and sucrose tolerance tests were performed as described before [28]. Twenty fasted diabetic and non-diabetic rats were divided into four groups of five each, and orally treated with $10 \mathrm{mg} / \mathrm{kg}$ body weight of the protein from MCC, MCM, Acarbose (positive control) or distilled water (negative control). Ten minutes after the treatment, blood glucose level was estimated ( $0 \mathrm{~min})$, and the rats were orally administered with $3.0 \mathrm{~g} / \mathrm{kg}$ starch or $4.0 \mathrm{~g} / \mathrm{kg}$ sucrose. Blood glucose level (BG) was estimated 30, 60 and 120 min after the administration. Peak blood glucose (PBG) was determined by observing the blood glucose level during the above mentioned time intervals and area under the curve (AUC) was calculated using the formula given below

$$
\begin{aligned}
\mathrm{AUC}(\mathrm{mg} / \mathrm{dL} . \mathrm{H})= & \left(\mathrm{BG}_{0}+\mathrm{BG}_{30} \times 0.5\right) / 2 \\
& +\left(\mathrm{BG}_{30}+\mathrm{BG}_{60} \times 0.5\right) / 2 \\
& +\left(\mathrm{BG}_{60}+\mathrm{BG}_{120} \times 1.0\right) / 2
\end{aligned}
$$

wherein $\mathrm{BG}_{0}$ is the blood glucose level before oral administration of starch and glucose, and $\mathrm{BG}_{30}, \mathrm{BG}_{60}$, and $\mathrm{BG}_{120}$ are the blood glucose level 30, 60 and $120 \mathrm{~min}$ after the administration.

\section{Statistical analysis}

All experiments were performed in triplicate. Means, standard errors, and standard deviations were calculated from replicates within the experiments. Statistical analysis was done by one way analysis of variance (ANOVA). Statistical significance was accepted at $P<$ 0.05. IC50 was calculated using graph pad prism software.

\section{Results}

\section{a -amylase inhibition assay}

Fruit pulp of $M$. charantia var. charantia (MCC) and $M$. charantia var. muricata (MCM) yielded 0.07 and $0.025 \%$ proteins on wet weight basis, respectively. Inhibition of $\alpha$-amylase activity by the protein extracts from MCC, MCM and Acarbose was found to be dose dependent from 0.5 to $2.5 \mathrm{mg} / \mathrm{ml}$ concentrations (Fig. 1). A maximum of $66.5,67$ and $68 \%$ inhibition of $\alpha$-amylase activity was observed at $2.5 \mathrm{mg} / \mathrm{ml}$ concentration for the protein extracts from MCC, MCM and Acarbose, respectively. Heat denatured protein extracts from $\mathrm{MCC}$ and 


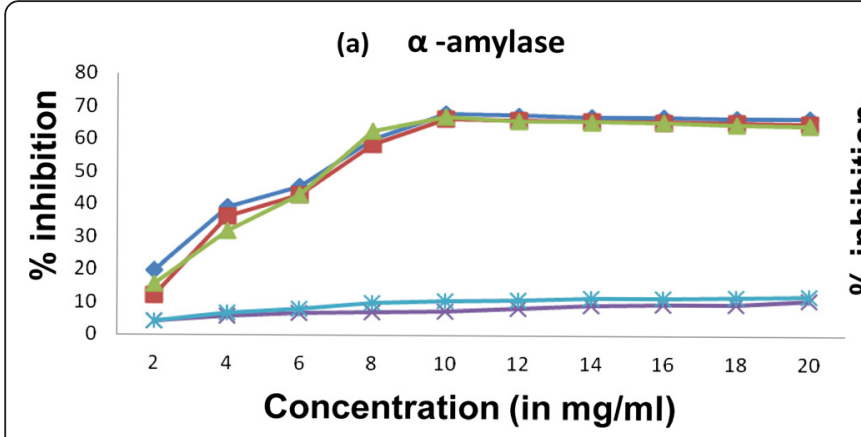

(b) $\alpha$-glucosidase
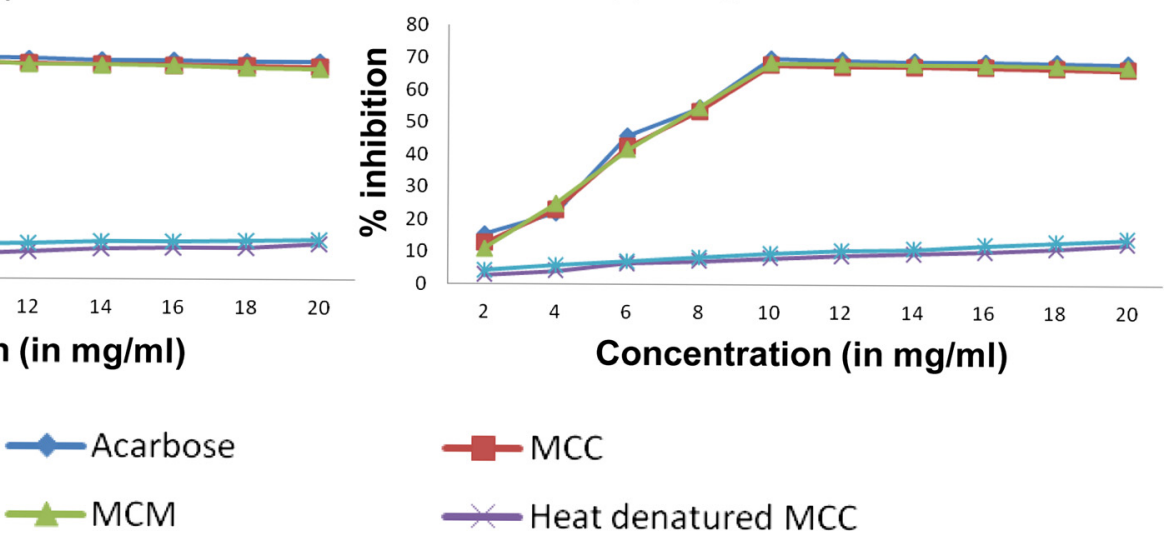

$-\mathrm{MCC}$

$-\mathrm{MCM}$

$\longrightarrow$ Heat denatured MCC

- Heat denatured MCM

Fig. 1 Percentage inhibition of a-amylase (a) and a-glucosidase (b) enzyme activity at different concentrations of Acarbose, protein extracts from MCC and MCM, and heat denatured protein extracts from MCC and MCM

MCM showed only a maximum of $11 \% \alpha$-amylase inhibition activity at this concentration. The IC50 was $0.267 \pm$ $0.024,0.261 \pm 0.019$, and $0.258 \pm 0.017 \mathrm{mg} / \mathrm{ml}$ for the protein extracts from MCC, MCM, and Acarbose, respectively (Table 1). The percentage inhibition of $\alpha$-amylase activity and IC50 of the protein extracts from MCC and MCM was highly significant $(P<0.05)$ when compared with the heat denatured protein extracts but not with Acarbose.

\section{a -glucosidase inhibition assay}

Ability of the protein extracts from MCC and MCM to inhibit $\alpha$ - glucosidase enzyme activity was determined at different concentrations between 0.5 and $5.0 \mathrm{mg} / \mathrm{ml}$. Protein extracts from both MCC and MCM showed $\alpha$-glucosidase inhibition activity in a dose dependant manner from 0.5 to $2.5 \mathrm{mg} / \mathrm{ml}$ concentration (Fig. 1). A maximum of $68.8,69.2$ and $70 \%$ inhibition of $\alpha$-glucosidase activity was observed at $2.5 \mathrm{mg} / \mathrm{ml}$ concentration for the protein extracts from MCC, MCM and Acarbose, respectively. Heat denatured protein extracts from MCC and MCM showed only a maximum of $10 \% \alpha$-glucosidase inhibition activity at this concentration. The IC50 was $0.298 \pm 0.034,0.292 \pm 0.022$, and $0.28 \pm 0.019 \mathrm{mg} / \mathrm{ml}$ for the protein extracts from MCC, MCM, and Acarbose, respectively (Table 1). The percentage inhibition of $\alpha$-glucosidase activity and IC50 of protein

Table 1 IC50 values of Acarbose and protein extracts from MCC and MCM for a-amylase and a-glucosidase inhibition

\begin{tabular}{|c|c|c|}
\hline \multirow[t]{2}{*}{ Analyte } & \multicolumn{2}{|l|}{ IC50 (mg/ml) } \\
\hline & a-amylase & a-glucosidase \\
\hline Acarbose & $0.258 \pm 0.017$ & $0.28 \pm 0.019$ \\
\hline MCC & $0.267 \pm 0.024$ & $0.298 \pm 0.034$ \\
\hline MCM & $0.261 \pm 0.019$ & $0.292 \pm 0.022$ \\
\hline
\end{tabular}

extracts from MCC and MCM was highly significant $(P<$ $0.05)$ when compared with heat denatured protein extracts but not with Acarbose.

\section{Analysis of proteolytic activity}

Treatment with the protein extracts from MCC and MCM did not degrade $\alpha$-amylase, $\alpha$-glucosidase or the mixture of six unrelated proteins. The same result was observed when the protein extracts were heat denatured before the treatment. Treatment with Proteinase K showed complete degradation of the proteins (Fig. 2).

\section{Mode of inhibition assay}

In the presence of the protein extracts from MCC and MCM, $\mathrm{K}_{\mathrm{m}}$ increased (3.214 to 4.235 and 4.583) but $\mathrm{V}_{\max }$ remained constant, which indicated competitive inhibition of the $\alpha$-amylase enzyme activity (Fig. 3 ). The same mode of inhibition was observed against $\alpha$-glucosidase enzyme also because $\mathrm{K}_{\mathrm{m}}$ increased from 3.734 to 4.564 (MCC) and $4.789(\mathrm{MCM})$ but $\mathrm{V}_{\max }$ remained constant (Fig. 3).

\section{Oral starch and sucrose tolerance tests}

In both oral starch and sucrose tolerance tests, the groups that were treated with the protein extracts from MCC and MCM showed significant lowering of PBG and AUC when compared with the diabetic control group but not with the Acarbose-treated group (Fig. 4, Table $2, P<0.05)$. In the groups that were treated with the protein extracts from MCC and MCM, the glucose level was reduced after $30 \mathrm{~min}$ in starch tolerance test, but only after $60 \mathrm{~min}$ in sucrose tolerance test. In Acarbose-treated group, the glucose level was reduced after $60 \mathrm{~min}$ in both the tests. 


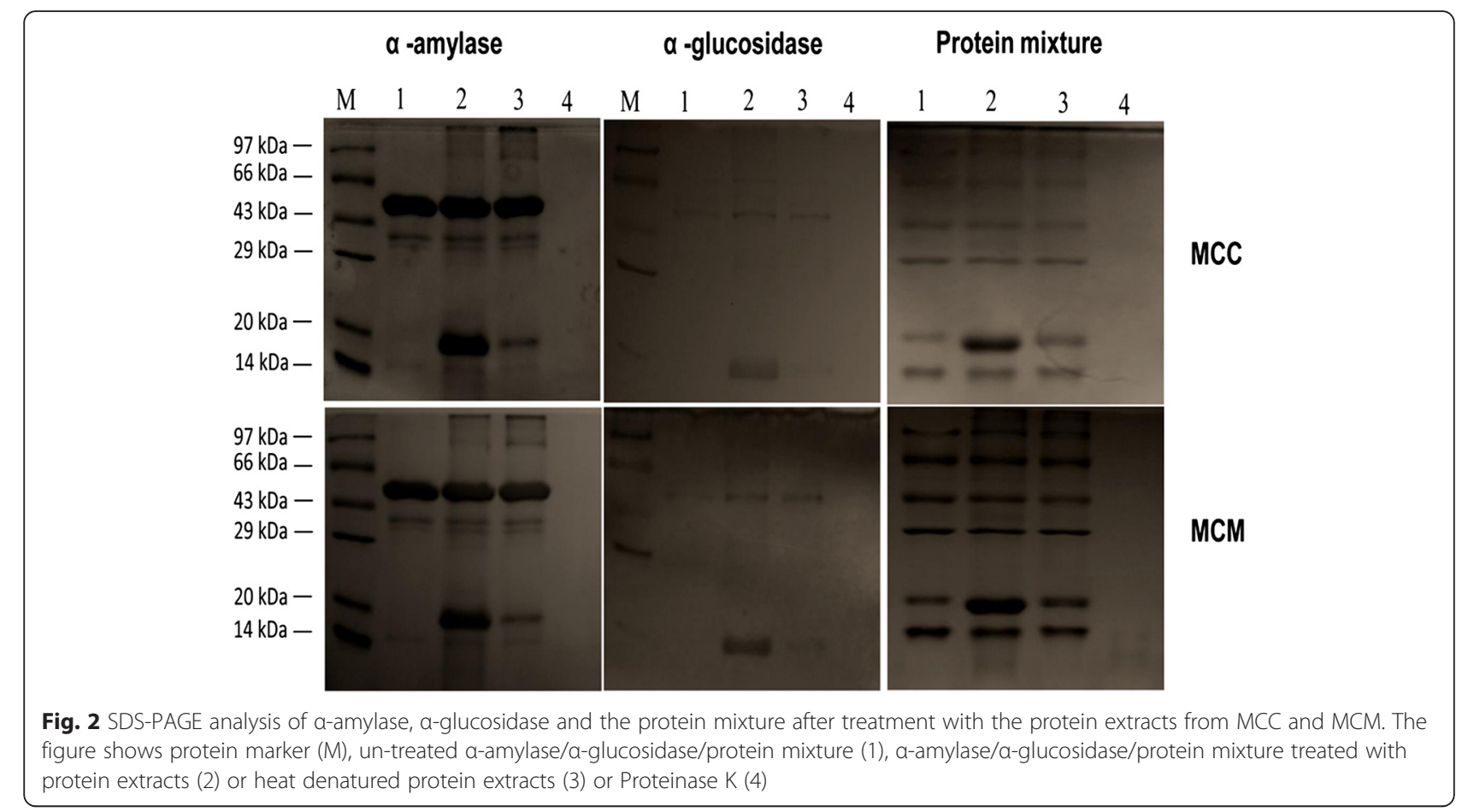

\section{Discussion}

Undesirable side effects and high cost of the currently available synthetic $\alpha$-glucosidase inhibitors drive the need to explore the natural sources for new inhibitors. Being a global lifestyle disorder that affects millions of people with diverse genetic backgrounds, the search for alternate inhibitors is also desirable from the pharmacogenetics point of view. Crude extracts and purified compounds from $M$. charantia were reported to show anti-diabetic activities, which includes $\alpha$-glucosidase inhibitory activity of the

\section{a -amylase}
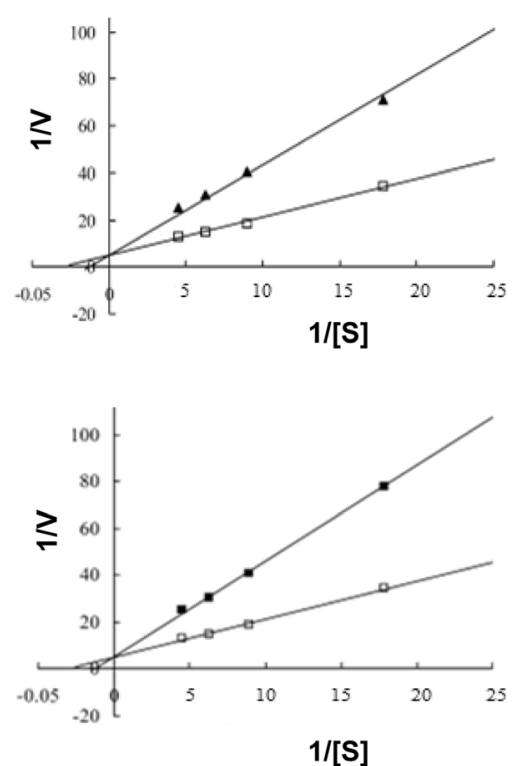

\section{$\alpha$-glucosidase}

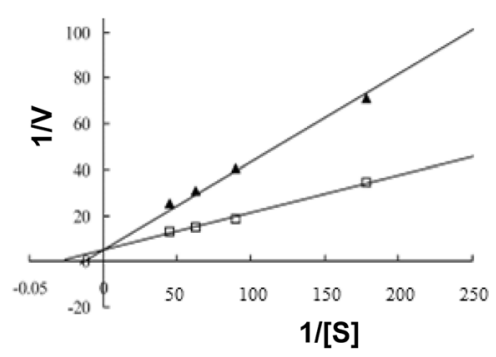

MCC

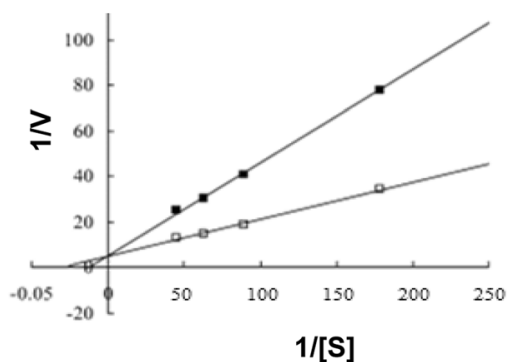

MCM

Fig. 3 Lineweaver-Burk plots analysis of inhibition kinetics of a-amylase and a-glucosidase enzymes by the protein extracts from MCC and MCM. $\boldsymbol{\Lambda}, \mathbf{\square}, 10 \mathrm{mg} / \mathrm{ml}$ protein extracts; $\square 20 \mathrm{mM}$ phosphate buffer 


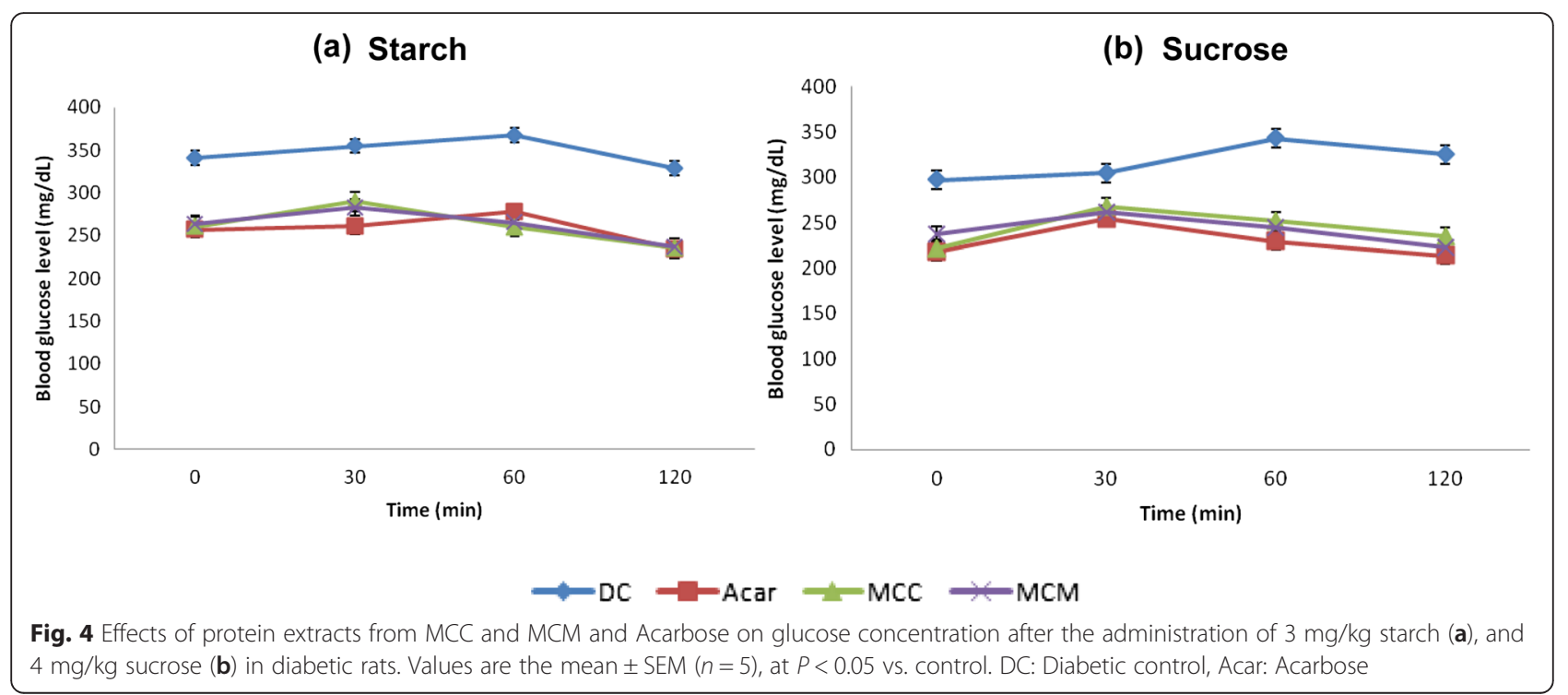

methanol and aqueous extracts [18-20]. However, $\alpha-$ amylase inhibiting activity was not reported for any extract or pure compound from this plant, and its protein extract was not studied for enzyme inhibitors against either $\alpha$-amylase or $\alpha$-glucosidase. Prospective inhibitors for controlling PPHG should have the ability to inhibit both $\alpha$-amylase and $\alpha$-glucosidase with higher percentage of inhibition and lower IC50. Therefore, protein extracts from M. charantia var. charantia (MCC) and M. charantia var. muricata (MCM) were studied for their ability to inhibit both $\alpha$-amylase and $\alpha$-glucosidase enzymes in vitro.

A few studies have reported that $\alpha$-amylase and $\alpha$ glucosidase inhibitory activity of Acarbose may range between 55 and $82 \%$ depending on the experimental conditions $[14,15,29]$. In our study, $10 \mathrm{mg} / \mathrm{ml}$ Acarbose showed 68 and $70 \%$ inhibition of $\alpha$-amylase and $\alpha$-glucosidase activity, respectively. Under the same experimental conditions, the protein extracts from both MCC and MCM showed enzyme inhibition and IC50 on par with Acarbose. To our knowledge, this is the first report of a protein extract from the same plant showing both $\alpha$-amylase and $\alpha$ glucosidase inhibitor activities. It remains to be studied if these two activities are contributed by a single protein or different proteins. Near complete abolition of the enzyme inhibitory activities was observed when the protein extracts from MCC and MCM were heat denatured before the treatment. This indicated that the inhibitory compounds present in the extracts may be protein in nature, though inhibition due to other thermo-labile compounds cannot be ruled out.

The protein extracts from MCC and MCM did not show proteolytic activity against $\alpha$-amylase, $\alpha$-glucosidase or the mixture of six unrelated proteins, which indicated the absence of proteolytic activity that is specific against these enzymes or non-specific against proteins. Therefore, the protein extracts do not contain any compound, which

Table 2 Effect of Acarbose and the protein extracts from MCC and MCM on peak blood glucose (PBG) and area under the curve (AUC) after starch $(3 \mathrm{~g} / \mathrm{kg}$ ) and sucrose $(4 \mathrm{~g} / \mathrm{kg})$ loading in diabetic and non- diabetic rats. Values are the mean $\pm \mathrm{SEM}(n=5)$, at $P<0.05 \mathrm{vs}$. control

\begin{tabular}{|c|c|c|c|c|c|c|c|c|}
\hline \multirow[t]{2}{*}{ Group } & \multicolumn{4}{|l|}{ Starch } & \multicolumn{4}{|l|}{ Sucrose } \\
\hline & $\begin{array}{l}\mathrm{PBG} \\
(\mathrm{mg} / \mathrm{dL})\end{array}$ & $\begin{array}{l}\text { \% Reduction } \\
\text { of PBG }\end{array}$ & $\begin{array}{l}\mathrm{AUC} \\
(\mathrm{mg} / \mathrm{dL})\end{array}$ & $\begin{array}{l}\% \text { Reduction } \\
\text { of AUC }\end{array}$ & $\begin{array}{l}\text { PBG } \\
(\mathrm{mg} / \mathrm{dL})\end{array}$ & $\begin{array}{l}\% \text { Reduction } \\
\text { of PBG }\end{array}$ & $\begin{array}{l}\text { AUC } \\
(\mathrm{mg} / \mathrm{dL})\end{array}$ & $\begin{array}{l}\% \text { Reduction } \\
\text { of AUC }\end{array}$ \\
\hline Diabetic control & $367.5 \pm 0.87$ & & $702.7 \pm 0.97$ & & $343 \pm 0.92$ & & $646 \pm 0.79$ & \\
\hline Diabetic + Acarbose & $277.8 \pm 0.76$ & 24.43 & $520.2 \pm 0.59$ & 25.97 & $254.3 \pm 0.69$ & 25.86 & $470 \pm 0.88$ & 27.24 \\
\hline Diabetic + MCC & $289.8 \pm 0.91$ & 21.15 & $524.8 \pm 0.65$ & 25.32 & $267 \pm 0.75$ & 22.16 & $474.5 \pm 0.95$ & 26.55 \\
\hline Diabetic + MCM & $282.8 \pm 0.82$ & 23 & $522.8 \pm 0.78$ & 25.6 & $261 \pm 0.87$ & 23.91 & $472 \pm 0.58$ & 26.94 \\
\hline Control & $172 \pm 0.56$ & & $382 \pm 0.63$ & & $184 \pm 0.81$ & & $394 \pm 0.64$ & \\
\hline Acarbose & $151 \pm 0.81$ & 12.2 & $305.4 \pm 0.67$ & 20.05 & $146 \pm 0.94$ & 20.65 & $295.4 \pm 0.56$ & 25.03 \\
\hline $\mathrm{MCC}$ & $161.2 \pm 0.65$ & 6.28 & $319.1 \pm 0.82$ & 16.47 & $153.8 \pm 0.73$ & 16.41 & $308.8 \pm 0.52$ & 21.62 \\
\hline MCM & $155 \pm 0.65$ & 9.88 & $309.8 \pm 0.56$ & 18.9 & $150.2 \pm 0.67$ & 18.37 & $301.6 \pm 0.82$ & 23.45 \\
\hline
\end{tabular}


inhibits the activity by cleaving the enzymes. The Lineweaver-Burk plot showed that the protein extracts inhibit the $\alpha$-amylase and $\alpha$-glucosidase enzymes by competitive binding.

Enzyme inhibitory activity of the protein observed in vitro is often not maintained in vivo, especially in case of oral administration of protein extract which is confronted by proteolytic enzymes and harsh $\mathrm{pH}$ conditions. However, orally administered proteins and peptides from plants have shown significant decrease in blood glucose level indicating biologically functional activity in vivo [30,31]. We have tested the protein extracts from MCC and MCM in vivo in Streptozotocin-induced diabetic rats. Peak blood glucose (PBG) and area under the curve (AUC) were significantly reduced in the diabetic rats that were orally administered with the protein extracts after starch or sucrose loading. The protein extracts were able to lower the blood glucose level faster than Acarbose in starch-fed diabetic rats. These results demonstrated the glucose lowering effect of the protein extracts in vivo, possibly due to the $\alpha$-amylase and $\alpha$ glucosidase inhibiting activities observed in vitro. However, further experiments will be needed to confirm the same or to find other possible mechanisms. Earlier studies in $M$. charantia have shown insulin-mimetic and insulin secretagogue activities in the protein extract [24], and anti-oxidant activity in the aqueous extract [32]. Therefore, the protein extract from $M$. charantia may work against diabetes through multiple mechanisms to be useful for the holistic management of diabetes mellitus.

\section{Conclusion}

$M$. charantia is a traditional medicinal plant that is popularly used for the management of diabetes in complementary and alternative medicine, and several scientific lines of evidences were reported in favour of the same. The present study established that the protein extracts from two varieties of $M$. charantia do have $\alpha$ amylase and $\alpha$-glucosidase inhibiting activities in vitro and glucose lowering activity in vivo. Further research is needed to develop anti-diabetic oral protein drug from this natural source.

\footnotetext{
Abbreviations

ANOVA, analysis of variance; AUC, area under the curve; BG, blood glucose; IC50, half maximal inhibitory concentration; MCC, Momordica charantia var. charantia; MCM, Momordica charantia var. muricata; PBG, peak blood glucose; pNPG, p-nitrophenyl-a-D-glucopyranoside; PPHG, postprandial hyperglycemia; SDS-PAGE, sodium dodecyl sulfate- polyacrylamide gel electrophoresis
}

\section{Acknowledgements}

This project was supported by DST-INSPIRE program of Department of Science and Technology, Government of India (Dy.No.100/IFD/10685/2010-2011).

\section{Declarations}

The publication charges for this article was funded by DST-INSPIRE grant 100/IFD/10685/2010-2011.
This article has been published as part of BMC Complementary and Alternative Medicine Volume 16 Supplement 1, 2016: Proceedings of the Indian Genetics Congress 2015: Complementary and Alternative Medicine. The full contents of the supplement are available online at http:// bmccomplementalternmed.biomedcentral.com/articles/supplements/ volume-16-supplement-1.

\section{Authors' contributions}

MP and SP designed the study and prepared the manuscript. SP performed the study and data analysis. Both the authors reviewed the manuscript. Both authors read and approved the final manuscript.

\section{Competing interests}

The authors declare that they have no competing interests.

Published: 18 July 2016

\section{References}

1. International Diabetes Federation, IDF Diabetes Atlas: http://www.idf.org/ diabetesatlas/. Accessed 15 June 2015.

2. Gin H, Rigalleau V. Post-prandial hyperglycemia. Post-prandial hyperglycemia and diabetes. Diabetes Metab. 2000;4:265-72.

3. Lordan S, Smyth TJ, Soler-Vila A, Stanton C, Ross RP. The a-amylase and aglucosidase inhibitory effects of Irish seaweed extracts. Food Chem. 2013;141:2170-6.

4. Lebovitz HE. a-glucosidase inhibitors. Endocrinol Metab Clin North Am. 1997:26:539-51.

5. Van de Laar FA. a-glucosidase inhibitors in the early treatment of type 2 diabetes. Vasc. Health Risk Manag. 2008;4:1189-95.

6. Etxeberria U, de la Garza AL, Capion J, Martnez JA, Milagro Fl. Antidiabetic effects of natural plant extracts via inhibition of carbohydrate hydrolysis enzymes with emphasis on pancreatic a amylase. Expert Opin Ther Targets. 2012;16:269-97.

7. International Diabetes Federation, IDF Diabetes Atlas: http://www.idf.org/ diabetesatlas/. Accessed 10 June 2015.

8. Fatmawati S, Shimizu K, Kondo R, Ganoderol B. A potent a-glucosidase inhibitor isolated from the fruiting body of Ganoderma lucidum. Phytomedicine. 2011;18:1053-5.

9. Konishi K, Watanabe N, Saito M, Nakajima N, Sakaki T, Katayama T, Enomoto T. Isolation of a new phlorotannin, a potent inhibitor of carbohydratehydrolyzing enzymes, from the brown alga Sargassum patens. J Agr Food Chem. 2012:60:5565-70.

10. Orhan N, Aslan M, Süküroğlu M, Orhan D. In vivo and in vitro antidiabetic effect of Cistus laurifolius L. and detection of major phenolic compounds by UPLC-TOF-MS analysis. J Ethnopharmacol. 2013;146:859-65.

11. Panwar H, Calderwood D, Grant IR, Grover S, Green BD. Lactobacillus strains isolated from infant faeces possess potent inhibitory activity against intestinal $a-$ and beta-glucosidases suggesting anti-diabetic potential. Eur J Nutr. 2014:53:1465-74

12. Ali RB, Atangwho IJ, Kuar N, Ahmad M, Mahmud R, Asmawi MZ. In vitro and in vivo effects of standardized extract and fractions of Phaleria macrocarpa fruits pericarp on lead carbohydrate digesting enzymes. BMC Complement Altern Med. 2013:20:13-39.

13. Kim KT, Rioux LE, Turgeon SL. a-amylase and a-glucosidase inhibition is differentially modulated by Fucoidan obtained from Fucus vesiculosus and Ascophyllum nodosum. Phytochem. 2014;98:27-33.

14. Mohamed EAH, Siddiqui MJA, Ang LF, Sadikun A, Chan SH, Tan SC, et al. Potent a-glucosidase and a-amylase inhibitory activities of standardized $50 \%$ ethanolic extracts and sinensetin from Orthosiphon stamineus Benth as anti-diabetic mechanism. BMC Complement Altern Med. 2012;12:176-82.

15. Perez-Gutierrez RM, Damian-Guzman M. Meliacinolin: a potent aglucosidase and a-amylase inhibitor isolated from Azadirachta indica leaves and in vivo antidiabetic property in streptozotocin-nicotinamide-induced type 2 diabetes in mice. Biol Pharm Bull. 2012;35:1516-24.

16. Chatterjee KP. On the Presence of an Antidiabetic principle in Momordica Charantia. Indian J Physiol Pharmacol. 1963;7:240-4.

17. Kar A, Choudhary BK, Bandyopadhyay NG. Comparative evaluation of hypoglycaemic activity of some Indian medicinal plants in alloxan diabetic rats. J Ethnopharmacol. 2003;84:105-8. 
18. Matsuura H, Asakawa C, Kurimoto M, Mizutani J. a-glucosidase inhibitor from the seeds of balsam pear (Momordica charantia) and the fruit bodies of Grifola frondosa. Biosci Biotech Biochem. 2002;66:1576-8.

19. Uebanso T, Arai H, Taketani Y, Fukaya M, Yamamoto H, Mizuno A, et al. Extracts of momordica charantia suppress postprandial hyperglycemia in rats. J Nutr Sci Vitaminology. 2007;53:482-8.

20. Nhiem NX, Kiem PV, Minh CV, Ban NK, Cuong NX, Tung NH, et al. aglucosidase inhibition properties of cucurbitane-type triterpene glycosides from the fruits of momordica charantia. Chem Pharm Bull. 2010;58:720-4.

21. Ahmad N, Hassan MR, Halder H, Bennoor KS. Effect of Momordica charantia (Karolla) extracts on fastin7g and postprandial serum glucose levels in NIDDM patients. Bangladesh Med Res Counc Bull. 1999;25:11-3.

22. Baldwa VS, Bhandari CM, Pangaria A, Goyal RK. Clinical trial in patients with diabetes mellitus of an insulin-like compound obtained from plant source. Upsala J Med Sci. 1977:82:39-41.

23. Khanna P, Jain SC, Panagariya A, Dixit VP. Hypoglycemic activity of polypeptide-p from a plant source. J Nat Prod. 1981;44:648-55.

24. Yibchok-anun S, Adisakwattana S, Yao CY, Sangvanich P, Roengsumran S, Hsu WH. Slow acting protein extract from fruit pulp of Momordica charantia with insulin secretagogue and insulinomimetic activities. Biol Pharm Bull. 2006;29:1126-31.

25. Kwon Y, Apostolidis E, Shetty K. Inhibitory potential of wine and tea against a-amylase and a-glucosidase for management of hyperglycemia linked to type 2 diabetes. J Food Biochem. 2006;32:15-31.

26. Kim YM, Wang MH, Rhee HI. A novel a-glucosidase inhibitor from pine bark. Carbohydr Res. 2004;339:715-7.

27. Ali H, Houghton PJ, Soumyanath A. a-amylase inhibitory activity of some Malaysian plants used to treat diabetes; with particular reference to Phyllanthus amarus. J Ethnopharmacol. 2006;107:449-55.

28. Subramanian R, Asmawi MZ, Sadikun A. In vitro a-glucosidase and aamylase enzyme inhibitory effects of Andrographis paniculata extract and andrographolide. Acta Biochim Pol. 2008;55:391-8.

29. Olubomehin OO, Abo KA, Ajaiyeoba EO. a-amylase inhibitory activity of two Anthocleista species and in vivo rat model anti-diabetic activities of Anthocleista djalonensis extracts and fractions. J Ethnopharmacol. 2013;146:811-4.

30. Joshi BN, Munot H, Hardikar M, Kulkarni A. Orally active hypoglycemic protein from Costus igneus N. E Br Biochem Biophys Res Commun. 2013:436:278-82

31. Zhang H, Wang J, Liu Y, Sun B. Peptides derived from oats improve insulin sensitivity and lower blood glucose in streptozotocin-induced diabetic mice. J Biomed Sci. 2015;4:1-7.

32. Hamissou M, Smith AC, Carter Jr RE, Triplett II JK. Antioxidative properties of bitter gourd (Momordica charantia) and zucchini (Cucurbita pepo). Emir J Food Agric. 2013;25:641-7.

\section{Submit your next manuscript to BioMed Central and we will help you at every step:}

- We accept pre-submission inquiries

- Our selector tool helps you to find the most relevant journal

- We provide round the clock customer support

- Convenient online submission

- Thorough peer review

- Inclusion in PubMed and all major indexing services

- Maximum visibility for your research

Submit your manuscript at www.biomedcentral.com/submit

) Biomed Central 